\title{
PENGARUH PENGGUNAAN DAUN JAMBU BIJI DAN LARUTAN KAPUR TERHADAP KUALITAS NIRA SIWALAN
}

\author{
Kurrotul Hasanah, Askur Rahman, Darimiyya Hidayati \\ Program Studi Teknologi Industri Pertanian, Universitas Trunojoyo Madura \\ Korespondensi : Jl. Raya Telang, PO. Box, 2 Kamal, Bangkalan 69162 \\ E-mail : s_coer_r@yahoo.com
}

\begin{abstract}
Nira siwalan mudah mengalami kerusakan yang umumnya ditandai dengan rasanya yang asam, berbuih dan berlendir karena aktivitas mikroba yang memfermentasi gula pada nira.Penggunaan pengawet alami dapat mencegah kerusakan nira.Tujuan penelitian ini untuk mengetahui pengaruh penggunaan daun jambu biji dan larutan kapur terhadap kualitas nira siwalan selama penyimpanan 9 jam. Parameter penelitian meliputi $\mathrm{pH}$, total padatan terlarut, total asam tertitrasi turbiditas serta pengujian sensoris meliputi aroma, kejernihan dan rasa nira siwalan. Penelitian ini menggunakan Rancangan Split Plot (Petak Terbagi). Faktor petak utama adalah konsentrasi daun jambu biji segar yang terdiri dari $6 \%(\mathrm{~J} 1), 10 \%$ (J2) dan $14 \%$ (J3), sedangkan penambahan larutan kapur 0,5 ml dengan konsentrasi larutan kapur $1 \%(\mathrm{~K} 1)$, $2 \%$ (K2) dan $3 \%$ (K3) merupakan faktor anak petak dengan melakukan pengulangan sebanyak 3 kali. Hasil penelitian menunjukkan bahwa penggunaan daun jambu biji berpengaruh terhadap nilai $p H$, total asam tertitrasi, turbiditas, aroma dan kejernihan nira siwalan selama penyimpanan 9 jam, namun tidak berpengaruh terhadap nilai total padatan terlarut dan rasa nira siwalan. Penggunaan larutan kapur hanya berpengaruh terhadap nilai rasa nira siwalan, namun tidak berpengaruh terhadap nilai $\mathrm{pH}$, total padatan terlarut, total asam tertitrasi, turbiditas, aroma dan kejernihan nira siwalan. Sedangkan interaksi keduanya berpengaruh terhadap nilai $\mathrm{pH}$, total padatan terlarut, total asam tertitrasi, namun tidak berpengaruh terhadap nilai turbiditas, aroma, kejernihan dan rasa nira siwalan selama penyimpanan 9 jam.
\end{abstract}

Kata kunci : nira siwalan, pengawet, daun jambu biji, larutan kapur

\section{PENDAHULUAN}

Industri gula merah merupakan salah satu usaha yang telah dilakukan sejak zaman nenek moyang yang diwariskan secara turun temurun dan terus berkembang hingga saat ini.Salah satu bahan baku utama dalam pembuatan gula merah adalah nira siwalan. Kualitas nira siwalan yang dihasilkan setiap harinya bervariasi dikarenakan adanya beberapa faktor yaitu lingkungan dan kontaminasi mikroba.

Nira merupakan cairan yang keluar dari bunga pohon palma penghasil nira seperti kelapa, aren dan siwalan yang diperoleh dengan cara penyadapan. Adanya bahanbahan dari berbagai jenis gula seperti sukrosa, fruktosa, glukosa, dan maltosa menyebabkan rasa manis pada nira (Muchtadiet
al.,2010).Nira siwalan mudah mengalami kerusakan yang umumnya ditandai dengan rasanya yang asam, berbuih dan berlendir karena aktivitas mikrobayang memfermentasi gula yang terdapat pada nira. Kandungan sukrosa yang cukup tinggi pada nira siwalan dapat menjadi media atau substrat yang baik untuk pertumbuhan mikroba.

Kerusakan nira akan menurunkan kualitas gula merah terlebih pada sifat organoleptik. Nira yang rusak akan menghasilkan gula merah yang sulit dicetak atau cepat lembek sehingga menurunkan harga jual produk. Permasalahan ini perlu dikendalikan untuk menjaga kualitas nira. Salah satu usaha yang dilakukan untuk mencegah terjadinya kerusakan nira yaitu dengan pengawetan. 
Pada umumnya pengrajin gula merah menambahkan larutan kapur ke dalam penampung nira yang berfungsi sebagai pengikat zat-zat bukan gula, supaya mudah dipisahkan dari zat gulanya.Larutan kapur juga memiliki sifat sebagai pengawet. Menurut Muchtadiet al., (2010) kapur digunakan sebagai pengawet disebabkan oleh terbentuknya kalsium hidroksida yang bersifat desinfektan, menggumpalkan protein dan asam nukleat serta merusak dinding sel.

Daun jambu biji dapat digunakan untuk membunuh atau menghambat pertumbuhan bakteri, sehingga digolongkan sebagai zat antimikroba yang dapat digunakan sebagai pengawet nira. Menurut Naufalin et al., (2012) daun jambu biji dapat dimanfaatkan sebagai pengawet pada nira karena memiliki aktivitas antimikroba. Penggunaan daun jambu biji dan larutan kapur diharapkan dapat mempertahankan kualitas nira siwalan sebelum diproduksi menjadi gula merah.

\section{METODE PENELITIAN}

Penelitian ini dilaksanakan di Desa

Pasean, Kecamatan Pasean, Kabupaten Pamekasan dan di Laboratorium Teknologi Industri Pertanian Universitas Trunojoyo Madura pada bulan Maret sampai Mei 2014.

Alat yang digunakan yaitu $\mathrm{pH}$ meter, biuret, refraktometer dan spektrofotometer. Bahan yang digunakan dalam penelitian ini adalah nira siwalan, daun jambu biji segar yang masih muda, kapur tohor, aquades, indikator pp dan larutan $\mathrm{NaOH} 0,1 \mathrm{~N}$.

Metode yang digunakan dalam penelitian ini menggunakan rancangan Split Plot (Petak Terbagi). Faktor petak utama adalah konsentrasi daun jambu biji segar yang terdiri dari 6\% (J1), 10\% (J2) dan 14\% (J3), sedangkan penambahan larutan kapur $0,5 \mathrm{ml}$ dengan konsentrasi larutan kapur $1 \%(\mathrm{~K} 1)$, $2 \%(\mathrm{~K} 2)$ dan $3 \%$ (K3) merupakan faktor anak petak dengan melakukan pengulangan sebanyak 3 kali.

Parameter yang diamati adalah pengujian kimia meliputi pengukuran $\mathrm{pH}$ dengan $\mathrm{pH}$ meter (Muchtadi et al., 2010), total padatan terlarut menggunakan refraktometer (Nakneanet al.,2010), total asam tertitrasi dengan larutan $\mathrm{NaOH} 0,1 \mathrm{~N}$ dan larutan indikator phenolptalin (pp) (Muchtadi et al.,2010), turbiditas menggunakan spektrofotometer dengan panjang gelombang $650 \mathrm{~nm}$ (Naknean et al., 2010). Pengujian sensoris meliputi aroma, kejernihan dan rasa nira siwalan menggunakan uji skoring dengan skala 1 sebagai nilai terendah dan angka 5 untuk nilai tertinggi menggunakan panelis agak terlatih sebanyak 20 orang (Kartika, 1988) dalam (Suwardjono, 2001).

Pengolahan data dilakukan dengan SPSS 16.0 dan dianalisis dengan uji ANOVA (Analysis of Variance) pada taraf beda nyata $5 \% \quad(\mathrm{P}<0,05)$. Jika perlakuan berpengaruh nyata $(\mathrm{P}<0,05)$, dilanjutkan dengan uji beda nyata jujur (uji Tukey) untuk mengetahui perbedaan dari setiap perlakuan.

\section{HASIL DAN PEMBAHASAN}

\section{Pengujian pH Nira Siwalan}

Hasil analisis variansi menunjukkan bahwa konsentrasi daun jambu biji dan interaksi keduanya berpengaruh nyata $(\mathrm{P}<0,05)$ terhadap nilai $\mathrm{pH}$ nira siwalan, namun konsentrasi larutan kapur tidak berpengaruh nyata $(\mathrm{P} \geq 0,05)$ terhadap nilai $\mathrm{pH}$ nira siwalan.

Analisis Tabel 1 menunjukkan bahwa penambahan konsentrasi daun jambu biji memberikan pengaruh yang nyata terhadap nilai $\mathrm{pH}$ nira siwalan. $\mathrm{PH}$ awal nira siwalan yang diperoleh dari pengrajin gula merah di Desa Pasean, Kecamatan Pasean, Kabupaten Pamekasanmempunyai pH sebesar 6,2. Perlakuan daun jambu biji menunjukkan nilai $\mathrm{pH}$ lebih tinggi dibandingkan dengan kontrol (tanpa perlakuan). Perlakuan daun jambu biji 6\% (J1) mempunyai nilai $\mathrm{pH}$ paling tinggi sebesar 6,5. Hal ini menunjukkan bahwa penggunaan daun jambu biji sebagai pengawet nira dapat mempertahankan $\mathrm{pH}$ nira siwalan selama penyimpanan9 jam, hal tersebut terjadi karena pada daun jambu biji mengandung senyawa tanin.Kandungan tanin yang terdapat pada daun jambu biji bersifat sebagai zat antimikroba yang dapat menghambat terjadinya proses fermentasi oleh aktivitas mikroorganisme yang merombak kandungan gula pada nira, sehingga meningkatkan kandungan asam yang berdampak pada penurunan $\mathrm{pH}$ nira. 
Tabel 1. Pengaruh Penambahan Konsentrasi Daun Jambu Biji terhadap pH NiraSiwalan

\begin{tabular}{lc}
\hline Perlakuan & Nilai pH \\
\hline Kontrol & $5,7^{\mathrm{a}}$ \\
Daun jambu biji 6\% (J1) & $6,5^{\mathrm{c}}$ \\
Daun jambu biji 10\% (J2) & $6,1^{\mathrm{b}}$ \\
Daun jambu biji 14\%(J3) & $6,3^{\text {bc }}$ \\
\hline
\end{tabular}

Keterangan:Angka yang diikuti notasi huruf berbeda menunjukkan perbedaan nyata pada taraf $\mathrm{P}<0,05$

Tabel 2. Pengaruh Penambahan Konsentrasi Daun Jambu Biji danLarutan Kapur terhadap pH Nira Siwalan

\begin{tabular}{llcc}
\hline Daun & \multicolumn{3}{c}{ Larutan Kapur } \\
\cline { 2 - 4 } Jambu Biji & $1 \%(\mathrm{~K} 1)$ & $2 \%(\mathrm{~K} 2)$ & $3 \%(\mathrm{~K} 3)$ \\
\hline Kontrol & $5,700^{\mathrm{a}}$ & $5,700^{\mathrm{a}}$ & $5,700^{\mathrm{a}}$ \\
$6 \%(\mathrm{~J} 1)$ & $6,167^{\mathrm{b}}$ & $6,400^{\mathrm{bc}}$ & $6,933^{\mathrm{c}}$ \\
$10 \%(\mathrm{~J} 2)$ & $6,133^{\mathrm{b}}$ & $6,100^{\mathrm{ab}}$ & $6,067^{\mathrm{ab}}$ \\
$14 \%(\mathrm{~J} 3)$ & $6,400^{\mathrm{bc}}$ & $6,267^{\mathrm{b}}$ & $6,233^{\mathrm{b}}$ \\
\hline
\end{tabular}

Keterangan : Angka yang diikuti notasi huruf berbeda menunjukkan perbedaan nyata pada taraf $\mathrm{P}<0,05$

Tanin merupakan salah satu jenis senyawa fenol yang mempunyai rasa sepat dan mempunyai kemampuan menyamak kulit. Selain itu tanin juga dapat mengendapkan protein, alkaloid, dan gelatin (Sulistiono, 2014).Kandungan tanin yang terdapat pada daun jambu biji memiliki kemampuan mengendapkan protein sehingga dapat menghambat aktivitas enzim invertase yang merombak kandungan sukrosa pada nira menjadi gula pereduksi yang terdiri dari glukosa dan fruktosa dengan cara membentuk kompleks dengan protein (komponen penyusun enzim) yang dapat menghambat kerja enzimsehingga mempertahankan $\mathrm{pH}$ nira tetap tinggi selama penyimpanan 9 jam.

Analisis Tabel 2 menunjukkan bahwa nilaipH pada nira kontrol (tanpa perlakuan) mengalami penurunan paling rendah sebesar 5,7 yang berarti memiliki derajat keasamanpaling tinggi bila dibandingkan dengan nira yang ditambahkan daun jambu biji dan larutan kapur.

Selain daun jambu biji, penambahanlarutan kapur ke dalam nira dapat mempertahankan $\mathrm{pH}$ nira siwalan tetap tinggi selama penyimpanan 9 jam. Hal ini dikarenakan larutan kapur mempunyai sifat basa sedangkan nira memiliki sifat asam, sehingga larutan kapur dapat menetralkan sifat nira yang asam. Fitri (2008) juga menyatakan bahwa larutan kapur memiliki sifat basa sehingga dapat digunakan untuk menetralkan sifat asam pada nira. Penambahan larutan kapur ke dalam nira dapat menetralkan nira yang semula memiliki $\mathrm{pH}$ sekitar 5,5 menjadi naik sampai $\mathrm{pH} 7$ atau netral.

Nira yang diperoleh dari pengrajin gula merah di Desa Pasean, Kecamatan Pasean,Kabupaten Pamekasan mempunyai pHawal sebesar 6,2sebelum penyimpanan 9 jam. Penambahandaun jambu biji dan larutan kapur dengan konsentrasi berbeda dapat mempertahankan $\mathrm{pH}$ nira siwalan selama penyimpanan 9 jam yang mempunyai nilai $\mathrm{pH}$ antara 6,067-6,933 yang berarti memiliki derajat keasaman paling rendah. Nira yang sudah rusak mempunyai $\mathrm{pH}$ kurang dari 6 dan tidak dapat digunakan dalam pembuatan gula merah. Kandungan asam dan gula pereduksi yang tinggi pada nira yang telahterfermentasi akan mempercepat proses penggosongan (karamelisasi) selama pemasakan dan menyebabkan gula merah bersifat lebih higroskopis sehingga mudah lembek dalam penyimpanan.

Deptan (1993) menyatakan bahwa nirasegar mempunyai rasa manis, harum, tidak berwarna dan derajat keasamannya $(\mathrm{pH})$ antara 6-7.Nira yang sudah rusak mempunyai pH kurang dari 6 dan jika digunakan dalam pembuatan gula merah akan menurunkan kualitas gula merah yang dihasilkan. 


\section{Pengujian Total Padatan Terlarut (TPT) Nira Siwalan}

Hasil analisis variansi menunjukkan bahwa interaksikonsentrasidaun jambu bijidengan larutan kapur berpengaruh nyata $(\mathrm{P}<0,05)$ terhadap nilai total padatan terlarut nira siwalan, namun konsentrasi daun jambu biji dan konsentrasi larutan kapur tidak berpengaruh nyata $(\mathrm{P} \geq 0,05)$ terhadap nilai total padatan terlarut nira siwalan.

Analisis Tabel 3 menunjukkan bahwa nira yang ditambahkandaun jambu biji dan larutan kapur dengan konsentrasi berbeda mempunyai nilai total padatan terlarut lebih tinggi bila dibandingkan dengan nira kontrol (tanpa perlakuan) yang mengalami penurunan total padatan terlarut paling cepat sebesar $8 \%$ selama penyimpanan 9 jam. Hal ini menunjukkan bahwa proses fermentasi nira oleh aktivitas mikroorganisme yang merombak kandungan sukrosa nira menjadi gula reduksi dapat dihambat dengan penambahandaun jambu biji dan larutan kapursehingga dapat mempertahankan total padatan terlarut nira siwalan selama penyimpanan 9 jam. Marsigit (2005) juga mengungkapkan bahwa penambahan pengawet alami yang mengandung tanin dapat menghambat aktivitas khamir sehingga dapat mengurangi reaksi hidrolisis sukrosa menjadi gula reduksi.
Menurut Davis dan Johnson (1987)

dalam Sholikhah (2010) menyatakan komposisi nira siwalan $(\mathrm{g} / 100 \quad \mathrm{cc})$ mengandung total gula sebesar $10,93 \%$. Nira yang diperoleh dari pengrajin gula merah di Desa Pasean, Kecamatan Pasean,Kabupaten Pamekasan mempunyaitotal padatan terlarut sebesar $10,4 \%$ sebelum penyimpanan 9 jamdan setelah penyimpanan 9 jam nilai TPT nira siwalan pada semua perlakuan mengalami penurunansebesar 8\%9\%.Kandungan sukrosa pada nira siwalan dapat menjadi media atau substrat yang baik untuk pertumbuhan mikroba, sehingga kandungan gula nira mengalami penurunan karena terjadi proses fermentasi yang merombak sukrosa menjadi gula reduksi. Nakneanet al., (2010) juga mengungkapkan bahwa penurunan TPT nira disebabkan oleh aktivitas mikroorganisme yang memfermentasi kandungan gula pada nira.

\section{Pengujian Total Asam Tertitrasi (TAT) Nira Siwalan}

Hasil analisis variansi menunjukkan bahwa konsentrasi daun jambu biji dan interaksi keduanya berpengaruh nyata $(\mathrm{P}<0,05)$ terhadap nilai total asam tertitrasi nira siwalan, namun konsentrasi larutan kapur tidak berpengaruh nyata $(\mathrm{P} \geq 0,05)$ terhadap nilai total asam tertitrasi nira siwalan.

Tabel 3. Pengaruh Penambahan Konsentrasi Daun Jambu Biji dan Larutan Kapur terhadap Total Padatan Terlarut Nira Siwalan

\begin{tabular}{lccc}
\hline Daun & \multicolumn{3}{c}{ Larutan Kapur } \\
\cline { 2 - 4 } Jambu Biji & $1 \%(\mathrm{~K} 1)$ & $2 \%(\mathrm{~K} 2)$ & $3 \%(\mathrm{~K} 3)$ \\
\hline Kontrol & $8,000^{\mathrm{a}}$ & $8,000^{\mathrm{a}}$ & $8,000^{\mathrm{a}}$ \\
$6 \%(\mathrm{~J} 1)$ & $9,200^{\mathrm{b}}$ & $8,467^{\mathrm{a}}$ & $9,067^{\mathrm{b}}$ \\
$10 \%(\mathrm{~J} 2)$ & $8,933^{\mathrm{b}}$ & $9,067^{\mathrm{b}}$ & $9,067^{\mathrm{b}}$ \\
$14 \%(\mathrm{~J} 3)$ & $9,133^{\mathrm{b}}$ & $9,200^{\mathrm{b}}$ & $9,133^{\mathrm{b}}$ \\
\hline
\end{tabular}

Keterangan : Angka yang diikuti notasi huruf berbeda menunjukkan perbedaan nyata pada taraf $\mathrm{P}<0,05$ Tabel 4. Pengaruh Penambahan Konsentrasi Daun Jambu Biji terhadap Total Asam Tertitrasi Nira Siwalan

\begin{tabular}{lc}
\hline Perlakuan & Nilai TAT (\%) \\
\hline Kontrol & $0,061^{\mathrm{c}}$ \\
Daun jambu biji 6\% (J1) & $0,017^{\mathrm{a}}$ \\
Daun jambu biji 10\% (J2) & $0,020^{\mathrm{a}}$ \\
Daun jambu biji 14\% (J3) & $0,024^{\mathrm{b}}$ \\
\hline
\end{tabular}

Keterangan :Angka yang diikuti notasi huruf berbeda menunjukkan perbedaan nyata pada taraf $\mathrm{P}<0,05$ 
Analisis Tabel 4 menunjukkan bahwa penambahan konsentrasi daun jambu biji memberikan pengaruh yang nyata terhadap nilai total asam tertitrasi (TAT) nira siwalan.Pada perlakuan daun jambu biji menunjukkan nilai TAT lebih rendah dibandingkan dengan kontrol (tanpa perlakuan). Hal tersebut menunjukkan pada perlakuan daun jambu biji mempunyai kandungan total asam yang rendah, sedangkan pada kontrol mempunyai kandungan total asam yang paling tinggi. Perlakuan daun jambu biji 6\% (J1) mempunyai nilai TAT terendah sebesar $0,017 \%$ yang berarti mempunyai $\mathrm{pH}$ paling tinggi dan mempunyai kandungan total asam paling rendah.

Penggunaan daun jambu biji dapat menghambat terjadinya proses fermentasi gula pada nira. Kandungan sukrosa yang cukup tinggi pada nira dapat dijadikan media yang baik untuk pertumbuhan mikroorganisme seperti bakteri, kapang maupun khamir. Proses fermentasi menyebabkan penurunan pHnira yang mengakibatkan kandungan asam pada nira semakin meningkat.

Menurut Ajizah (2004) menyatakan bahwa daun jambu biji (Psidium guajava)selain mempunyai daya antidiare, ternyata juga bersifat antibakteri terhadap Salmonella typhimurium. Kandungan tanin yang terdapat pada daun jambu biji mempunyai daya antibakteri dengan cara mempresipitasi protein. Efek antibakteri tanin antara lain melalui reaksi dengan membran sel, inaktivasi enzim, dan destruksi atau inaktivasi fungsi materi genetik.

Analisis Tabel 5 menunjukkan bahwa nilai TAT tertinggi terdapat pada kontrol (tanpa perlakuan) yang berarti mempunyai kandungan asam nira siwalan paling tinggi dan memiliki nilai $\mathrm{pH}$ paling rendah, sedangkan pada nira yang ditambahkan daun jambu biji dan larutan kapur mempunyai nilai TAT lebih rendah yang berarti mempunyai kandungan asaml ebih rendah dan memiliki nilai $\mathrm{pH}$ lebih tinggi bila dibandingkan dengan kontrol (tanpa perlakuan).

Selain daun jambu biji, larutan kapur sebagai bahan pengawet dapat membentuk kalsium hidroksida yang bersifat desinfektan dan menggumpalkan protein sehingga dapat menghambat aktivitas mikroba yang menyebabkan keasaman pada nira siwalan. Penelitian Erwinda dan Wahono (2014) menyatakan bahwa penambahan kapur pada nira akan mempertahankan $\mathrm{pH}$ nira tetap tinggi, sehingga dapat menghambat terjadinya hidrolisa baik oleh jasad renik maupun pengaruh asam.Kapur $\left(\mathrm{CaCO}_{3}\right)$ di dalam air membentuk $\quad \mathrm{Ca}(\mathrm{OH})_{2}, \quad$ selanjutnya menghasilkan ion $\mathrm{OH}^{-}$bebas yang membuat larutan alkalis. Pada prinsipnya, penambahan kapur dalam nira akan menyebabkan kenaikan $\mathrm{pH}$ nira akibat ion $\mathrm{OH}^{-}$.Apabila keasaman nira dapat dikendalikan dengan penambahan kapur, laju inversi sukrosa menjadi glukosa dan fruktosa akan berkurang.

Pengujian Turbiditas (kekeruhan) Nira Siwalan

Hasil analisis variansi menunjukkan bahwa konsentrasi daun jambu biji berpengaruh nyata $(\mathrm{P}<0,05)$ terhadap nilai turbiditas nira siwalan, namun konsentrasi larutan kapur dan interaksi keduanya tidak berpengaruh nyata $(P \geq 0,05)$ terhadap nilai turbiditas nira siwalan.

Tabel 5. Pengaruh PenambahanKonsentrasi Daun Jambu Biji dan Larutan Kapur terhadap Total Asam Tertitrasi Nira Siwalan

\begin{tabular}{lccc}
\hline Daun & \multicolumn{3}{c}{ Larutan Kapur } \\
\cline { 2 - 4 } Jambu Biji & $1 \%(\mathrm{~K} 1)$ & $2 \%(\mathrm{~K} 2)$ & $3 \%(\mathrm{~K} 3)$ \\
\hline Kontrol & $0,061^{\mathrm{c}}$ & $0,061^{\mathrm{c}}$ & $0,061^{\mathrm{c}}$ \\
$6 \%(\mathrm{~J} 1)$ & $0,017^{\mathrm{a}}$ & $0,013^{\mathrm{a}}$ & $0,022^{\mathrm{ab}}$ \\
$10 \%(\mathrm{~J} 2)$ & $0,013^{\mathrm{a}}$ & $0,024^{\mathrm{b}}$ & $0,023^{\mathrm{ab}}$ \\
$14 \%(\mathrm{~J} 3)$ & $0,026^{\mathrm{b}}$ & $0,024^{\mathrm{b}}$ & $0,020^{\mathrm{ab}}$ \\
\hline
\end{tabular}

Keterangan :Angka yang diikuti notasi huruf berbeda menunjukkan perbedaan nyata pada taraf $\mathrm{P}<0,05$ 
Tabel 6.Pengaruh Penambahan Konsentrasi Daun Jambu Biji terhadap Turbiditas Nira Siwalan

\begin{tabular}{lc}
\hline Perlakuan & Nilai Turbiditas (Abs) \\
\hline Kontrol & $1,240^{\mathrm{c}}$ \\
Daun jambu biji 6\% (J1) & $0,970^{\mathrm{b}}$ \\
Daun jambu biji 10\% (J2) & $0,891^{\mathrm{a}}$ \\
Daun jambu biji 14\%(J3) & $0,914^{\mathrm{ab}}$ \\
\hline
\end{tabular}

Keterangan :Angka yang diikuti notasi huruf berbeda menunjukkan perbedaan nyata pada taraf $\mathrm{P}<0,05$

Tabel 7. Pengaruh Penambahan Konsentrasi Daun Jambu Biji terhadap Aroma Nira Siwalan

\begin{tabular}{lc}
\hline Perlakuan & Nilai Aroma \\
\hline Kontrol & $2,400^{\mathrm{a}}$ \\
Daun jambu biji 6\% (J1) & $3,367^{\mathrm{b}}$ \\
Daun jambu biji 10\%(J2) & $4,083^{\mathrm{c}}$ \\
Daun jambu biji 14\%(J3) & $3,583^{\mathrm{b}}$ \\
\hline
\end{tabular}

Keterangan : Angka yang diikuti notasi huruf berbeda menunjukkan perbedaan nyata pada taraf $\mathrm{P}<0,05$

Tabel 8. Pengaruh Penambahan Konsentrasi Daun Jambu Biji terhadap Kejernihan Nira Siwalan

\begin{tabular}{lc}
\hline Perlakuan & Nilai Kejernihan \\
\hline Kontrol & $1,900^{\mathrm{a}}$ \\
Daun jambu biji 6\% (J1) & $2,650^{\mathrm{b}}$ \\
Daun jambu biji 10\% (J2) & $2,917^{\mathrm{b}}$ \\
Daun jambu biji 14\% (J3) & $2,300^{\mathrm{a}}$ \\
\hline
\end{tabular}

Keterangan :Angka yang diikuti notasi huruf berbeda menunjukkan perbedaan nyata pada taraf $\mathrm{P}<0,05$

Tabel 9. Pengaruh Penambahan Konsentrasi Larutan Kapur terhadap Rasa Nira Siwalan

\begin{tabular}{lc}
\hline Perlakuan & Nilai Rasa \\
\hline Kontrol & $2,150^{\mathrm{a}}$ \\
Larutan Kapur 1\%(K1) & $2,567^{\mathrm{a}}$ \\
Larutan Kapur 2\% (K2) & $2,983^{\mathrm{b}}$ \\
Larutan Kapur 3\% (K3) & $2,733^{\mathrm{b}}$ \\
\hline
\end{tabular}

Keterangan : Angka yang diikuti notasi huruf berbeda menunjukkan perbedaan nyata pada taraf $\mathrm{P}<0,05$

Analisis Tabel 7 menunjukkan bahwa penambahan konsentrasi daun jambu biji memberikan pengaruh yang nyata terhadap penilaian panelis terhadap aroma nira siwalan.Semakin tinggi penilaian panelis terhadap aroma maka semakin tidak menyengat aroma nira siwalan. Perlakuan daun jambu biji menunjukkan nilai aroma nira siwalan lebih tinggi dibandingkan dengan kontrol (tanpa perlakuan).Pada perlakuan daun jambu biji $10 \%$ (J2) mempunyai penilaian panelis tertinggi terhadaparoma nira siwalan sebesar 4,083 yang menunjukkan aroma nira tidak menyengat, sedangkan penilaian panelis terendahterhadap aroma nirasiwalan terdapat pada kontrol (tanpa perlakuan) sebesar 2,4 yang menunjukkan aroma nira menyengat. Hal ini disebabkan pada nira kontrol (tanpa perlakuan) telah mengalami kerusakan.Suwardjono (2001) juga mengungkapkan terjadinya perubahan aroma nira disebabkan oleh aktivitas mikroba yang membentuk berbagai jenis asam pada nira sehingga menyebabkan aroma yang tidak dikehendaki.

\section{Analisis Kejernihan Nira Siwalan}

Hasil analisis variansi menunjukkan bahwa konsentrasi daun jambu biji berpengaruh nyata $(\mathrm{P}<0,05)$ terhadap nilai kejernihan nira siwalan, namun konsentrasi larutan kapur dan interaksi keduanya tidak berpengaruh nyata $(\mathrm{P} \geq 0,05)$ terhadap nilai kejernihan nira siwalan.

Analisis Tabel 8 menunjukkan bahwa penambahan konsentrasi daun jambu biji memberikan pengaruh yang nyata terhadappenilaian panelis terhadap kejernihan nira siwalan.Semakin tinggi penilaian panelis terhadap kejernihan maka semakin tinggi kejernihan nira siwalan.Pada perlakuan daun 
jambu biji menunjukkan penilaian panelis lebih tinggi terhadap kejernihan nira siwalan bila dibandingkan dengan kontrol (tanpa perlakuan). Penilaian panelis tertinggi terhadap kejernihan nira siwalan terdapat pada perlakuan daun jambu biji 10\% (J2) sebesar 2,917 yang menunjukkan warna nira cukup jernih, sedangkan pada kontrol (tanpa perlakuan) mengalami perubahan kejernihan paling cepat sebesar 1,9 yang menunjukkan nira keruh. Adanya aktivitas mikroorganisme pada nira menyebabkan nira yang semula jernih menjadi keruh dan sedikit berbuih setelah penyimpanan 9 jam.Suwardjono(2001) mengungkapkan perubahan kejernihan nira disebabkan adanya aktivitas mikroba yang semula nira jernih menjadi putih, berbuih dan agak berlendir.

\section{Analisis Rasa Nira Siwalan}

Hasil analisis variansi menunjukkan bahwa konsentrasi larutan kapur berpengaruh nyata $(\mathrm{P}<0,05)$ terhadap nilai rasa nira siwalan, namun konsentrasi daun jambu biji dan interaksi keduanya tidak berpengaruh nyata $(P \geq 0,05)$ terhadap nilai rasa nira siwalan.

Analisis Tabel 9 menunjukkan bahwa penambahan larutan kapur dengan konsentrasi berbeda memberikan pengaruh yang nyata terhadap penilaian panelis terhadap rasa nira siwalan.Semakin tinggi penilaian panelis terhadap rasa maka semakin manis rasa nira siwalan. Pada perlakuan larutan kapur menunjukkan penilaian panelis lebih tinggi terhadap rasa nira siwalan bila dibandingkan dengan kontrol (tanpa perlakuan).Pada perlakuan larutan kapur $2 \%$ (K2) mempunyaipenilaian panelistertinggi sebesar 2,983 terhadap rasa nira siwalan yang menunjukkan rasa nira siwalan cukup manis, sedangkan pada kontrol (tanpa perlakuan) menunjukkan penilaian panelis terendahterhadap rasa nira siwalan sebesar 2,150 yang menunjukkan rasa nira siwalan asam.Hal ini disebabkan terjadinya proses fermentasi yang dapat meningkatkan kandungan asam dan menurunkan $\mathrm{pH}$ nira, sehingga rasa nira menjadi asam.

Suwardjono (2001) mengungkapkan bahwa perubahan rasa asam pada nira kelapa setelah penyimpanan 9 jam karena terakumulasinya asam-asam yang terbentuk selama proses fermentasi. Hal ini disebabkan intensitas rasa asam karena meningkatnya ionion $\mathrm{H}^{+}$.

\section{KESIMPULAN}

Berdasarkan hasil penelitian dapat disimpulkan bahwa :

1. Penggunaan daun jambu biji berpengaruhterhadap nilai $\mathrm{pH}$, total asam tertitrasi, turbiditas, aroma dan kejernihan nira siwalan, namun tidak berpengaruh terhadap nilai total padatan terlarut dan rasa nira siwalan selama penyimpanan 9 jam.

2. Penggunaan larutan kapur hanya berpengaruh terhadap nilai rasa nira siwalan, namun tidak berpengaruh terhadap nilai $\mathrm{pH}$, total padatan terlarut, total asam tertitrasi,turbiditas, aroma dan kejernihan nira siwalan. Sedangkan interaksi keduanya berpengaruh terhadap nilai $\mathrm{pH}$, total padatan terlarut, total asam tertitrasi, namun tidak berpengaruh terhadap nilai turbiditas, aroma, kejernihan dan rasa nira siwalan selama penyimpanan 9 jam. 
DAFTAR PUSTAKA

Ajizah, A. 2004. Sensitivitas Salmonella typhymurium Terhadap Ekstrak Daun Jambu Biji (Psidium guajava linn). Bioscientiae, Volume I, No. 1: 31-38. Program Studi Biologi FMIPA. Universitas Lambung Mangkurat.

Deptan. 1993.Membuat Gula Kelapa. Lembar Informasi Pertanian (LIPTAN) BIP Irian Jaya No. 124/93. Balai Informasi Pertanian Irian Jaya.

Erwinda, M. D. dan W. H. Susanto. 2014. Pengaruh pH Nira Tebu (Saccharum officinarum) dan Konsentrasi Penambahan Kapur Terhadap Kualitas Gula Merah. Jurnal Pangan dan Agroindustri, Vol. II, No. 3: 54-64. Jurusan Teknologi Hasil Pertanian. Universitas Brawijaya Malang.

Fitri, Y. F. 2008. Pengaruh Penambahan Susu Kapur $(\mathrm{CaOH})_{2}$ dan $\mathrm{Gas} \mathrm{SO}_{2}$ Terhadap pH Nira Mentah Dalam Pemurnian Nira di Pabrik Gula Kwala Madu PTP Nusantara II Langkat. [Karya Ilmiah]. Medan. Universitas Sumatera Utara.

Marsigit, W. 2005.Penggunaan Bahan Tambahan pada Nira dan Mutu Gula Aren yang Dihasilkan di Beberapa Sentra Produksi di Bengkulu. Jurnal Penelitian UNIB, 11(1): 42-48.

Muchtadi, T. R., Sugiyono dan F. Ayustaningwarno. 2010. Ilmu Pengetahuan Bahan Pangan. Alfabeta. Bandung.

Naknean, P., Meenune, M. dan Roudaut, G. 2010.Characterization of Palm Sap Harvested in Songkhla Province, Southern Thailand. International Food Research Journal, 17: 977-986.

Naufalin, R., T. Yanto dan A. G. Binardjo. 2012. Penambahan Konsentrasi $\mathrm{Ca}(\mathrm{OH})_{2}$ dan Bahan Pengawet Alami untuk Peningkatan Kualitas Nira Kelapa. Jurnal Pembangunan Pedesaan, Vol. 12, No. 2: 86-96.

Sholikhah, S. M. 2010. Kajian Kadar Etanol dan Asam Asetat Dalam Cairan Nira Siwalan (Borassus flabellifer Linn.) Menggunakan Metode Kromatografi Gas (GC). [Skripsi]. Fakultas Sains Dan Teknologi. Universitas Islam Negeri (UIN) Maulana Malik Ibrahim Malang.
Sulistiono, D. A. 2014. http:// ml.scribd.com/doc/33507735/TANNIN diakses pada tanggal 23 Mei 2014.

Suwardjono. 2001. Pengaruh Penggunaan Bahan Pengawet Alam terhadap Kualitas Nira Kelapa yang Digunakan untuk Pembuatan Gula Kelapa Di Daerah Istimewa Yogyakarta. [Laporan Penelitian]. Lembaga Penelitian. Universitas Terbuka. 